\title{
Op je sodemieter krijgen. De algemene aanvaarding van sodomie en prostitutie in de late middeleeuwen in Europa
}

\author{
Nina Oosting
}

\section{Inleiding}

Geschiedenislessen leren ons over belangrijke veldheren en beroemde koningen die belangrijke rollen speelden in tijden van oorlog en vrede. Slechts af en toe komen verhalen over heldhaftige of opvallende burgers aan bod. Er is immers veel minder bekend over het leven van wat het gewone volk genoemd wordt. Uiteraard vinden we er gegevens over maar men schreef kennelijk makkelijker over roemruchtige personen.

Het leven van de kleine man fascineert mij en nog meer als het gaat over minder voor de hand liggende onderwerpen. Zo kwam ik bij een verhaal over John Rykener ${ }^{1}$ een mannelijke prostituee in vrouwenkleding. Het lijkt me overigens een zeer apart en, voor de eenentwintigste-eeuwer althans, grappig verhaal. Hoewel grappig, ook al is het gerelateerd aan gender en seksualiteit, het blijft tot op de dag van vandaag een moeilijk maar intrigerend onderwerp, dat verder onderzoek verdiende. Daarom besloot ik deze tekst uit te diepen. Prostitutie is immers van alle tijden. Men

108 zegt niet voor niets dat het 'het oudste beroep ter wereld' is. Uit nieuwsgierigheid, interesse en vermaak koos lk voor het verhaal als brontekst.

De tekst bleek reeds aan ruim onderzoek te zijn onderworpen. Nadat ik eenmaal mijn brontekst had uitgekozen, ging ik op zoek naar ondersteunende literatuur. Hierdoor kwam ik te weten dat de tekst was gebruikt door de schrijvers David Lorenzo Boyd en Ruth Mazo Karras. Hierna probeerde ik onderzoeksvragen te ontwikkelen. De verdere uitdieping van het onderwerp verliep via de datebase van de bibliotheek van de universiteit Gent, wat verschillende hits opleverde in zowel de universiteitsbibliotheek van de UGent als de vakbibliotheek Middeleeuwse Geschiedenis van dezelfde universiteit.

Bij mijn lectuur kwam ik verscheidene auteursnamen frequent 
tegen die vaak naar elkaar refereerden: ze baseerden zich op elkaar of hadden van elkaar informatie gebruikt. Materiaal van een van deze frequent opduikende auteurs, met name Karras, werd zoveel mogelijk geïntegreerd in onderstaande tekst.

Mannelijke prostitutie en travestie zijn een moeilijk onderwerp. $\mathrm{Er}$ is nauwelijks in historische bronnen iets over terug te vinden. Dit maakte het moeilijk om er informatie over te vinden. De onderstaande analyse heb ik dan ook gekaderd binnen de problematiek van sodomie en prostitutie in het algemeen.

Wat hierna volgt is de samenvatting van een tekst, opgesteld in het Latijn naar aanleiding van een rechtszaak die diende voor een burgerlijke rechtbank in Londen. Hoe het met de beklaagden is afgelopen weten we niet en evenmin of ze nadien door een kerkelijke rechtbank zijn aangepakt.

\section{Samenvatting van de brontekst}

De hoorzitting vond plaats op 11 december 1395. De aanwezigen waren John Fressh, de burgemeester van de stad Londen, de wethouders (Aldermen) van de stad Londen, medeverdachte John Britby uit het graafschap York en hoofdverdachte John Rykener.

Rykener werd op de vorige zondagavond tussen acht en negen uur betrapt door ambtenaren, in vrouwenkleding, bij een zekere stalling in Soper's Lane, terwijl hij 'de onuitsprekelijke en detestelijke daad' uitvoerde.

John Britby bekende dat hij zich op het genoemde tijdstip op de hoofdweg van Cheap bevond. Hij kwam Rykener tegen en dacht dat het een vrouw was. Britby vroeg aan Rykener of hij samen met hem een 'lustvolle daad' wilde begaan. In ruil voor geld stemde Rykener in en de twee gingen naar de genoemde stal om 'de daad' te verrichten en werden alzo betrapt door de ambtenaren. Rykener heeft alles bekend.

Rykener werd ook gevraagd wie hem de uitoefening van deze 'zede' heeft geleerd en hoe lang en op welke plaatsen en met welke personen (mannelijk en/of vrouwelijk) hij 'de daad' beging. Een zekere Anna, een prostituee en een vroegere dienstbode van Sir Thomas Blount, had hem als eerste de daad geleerd op de manier van een vrouw, terwijl een zekere Elizabeth Bronderer hem voor het eerst in vrouwenkleding had gestoken. Een zekere 
Phillip, rector van Theydon Garnon, had seks met hem als met een vrouw, bij Elizabeth Bronderer's buiten Bishopsgate. Rykener heeft toen twee kleden van Phillip genomen en wanneer die erom vroeg, antwoordde Rykener dat hij de echtgenote van een zekere man was en als hij ze terugwilde, haar echtgenoot dan een zaak tegen hem zou aanspannen.

Rykener bekende dat hij vijf weken voor het afgelopen feest van St. Michael in Oxford was en daar werkte als een vrouwelijke borduurster. Daar had hij met drie ongelovige geleerden, Sir William Foxlee, Sir John en Sir Walter, de 'onuitsprekelijke daad' vaak uitgevoerd. Rykener bekende eveneens dat hij de vrijdag voor het feest van St. Michael naar Burford in Oxfordshire was gegaan en daar met een zekere John Clerk in de Swan woonde voor de volgende zes weken. Daar had hij met twee franciscanen, broeder Michael en broeder John, een karmelieterbroeder en zes buitenlandse mannen de voorgenoemde daad begaan.

Rykener bekende ook dat hij naar Beaconsfield ging en daar, als een man, seks had met een zekere Joan, dochter van John Matthew. Op dezelfde plek hadden twee buitenlandse franciscanen seks met hem als met een vrouw.

Rykener bekende verder dat na zijn laatste terugkeer naar Londen een zekere Sir John, ooit kapelaan bij de kerk van St. Margeret Pattens, en twee andere kapelaans met hem 'de onuitsprekelijke daad' begingen in de lanen achter St. Catharina's kerk bij de Tower van Londen. Rykener bekende ook dat hij vaak als man

110 seks had met nonnen en met veel vrouwen die zowel getrouwd als ongetrouwd waren. Ook vele priesters begingen 'de daad' met hem als vrouw.

\section{Onderzoeksvragen}

Deze tekst roept meteen een aantal vragen op. Naarmate mijn onderzoek vorderde heb ik de vragen wat moeten aanpassen. Door middel van de gevormde deelvragen heb ik uiteindelijk geprobeerd de hoofdvraag te beantwoorden. De volgende vragen zijn het uiteindelijke resultaat.

Hoe ver ging de algemene aanvaarding van sodomie en prostitutie in de late middeleeuwen in Europa? Hoe kwamen travestie en genderwisseling voor in de late middeleeuwen? In hoeverre werden prostitutie en sodomie getolereerd door de samenleving? 
Wat werd getolereerd qua prostitutie? En wat op het stuk van sodomie? Wat was de rol van de clerus in de prostitutie?

\section{Vergelijkingen tussen de brontekst en de gevonden literatuur}

\section{Verduidelijking van sodomie}

Onder sodomie werd door de eeuwen heen meerdere en verschillende dingen verstaan, zoals homoseksualiteit, travestie, anale seks, zelfbevrediging en zelfs bestialiteit. Eigenlijk bijna alles wat 'ongewoon' was voor seks. Alles wat niet te maken had met de voortplanting, werd als sodomie beschreven. Omdat sodomie dus nogal een breed begrip is, zal ik een afbakening maken.

Deze tekst gaat het voornamelijk over prostitutie, homo- (en hetero-) seksualiteit en travestie. Met sodomie wordt er in de onderstaande tekst voornamelijk homoseksualiteit en travestie tezamen bedoeld. Waar nodig gebruik ik nadrukkelijk de specifieke term.

\section{De brontekst}

Overal in Europa is er kennis en documentatie over homoseksualiteit en sodomie beschikbaar die evenwel zeer ongelijk verdeeld is. Zo bestaan er een flink aantal voorbeelden uit Italië en Engeland maar het aantal is veel kleiner in gebieden zoals Oost-Europa.

Het document over Rykener werd gevonden door de schrijvers David Lorenzo Boyd en Ruth Mazo Karras in 1995 en is blijkbaar de enige brontekst over dit onderwerp. ${ }^{2}$ Het is een schaars voorbeeld van sodomie en travestie in het Engeland van de late middeleeuwen. ${ }^{3}$ Persoonlijke beschrijvingen over seksualiteit uit die tijd zijn sowieso zeer gering aanwezig. Als ze al bestaan, vinden we ze vrijwel altijd in een wettelijke context. ${ }^{4}$ Ze zijn echter van groot belang voor de beschrijving van de middeleeuwse seksualiteit. Hoewel er niet veel historische documentatie is overgeleverd over travestie en homoseksuele prostitutie, is het document van Rykener zeer gedetailleerd. ${ }^{5}$

Algemene homoseksuele liefde kan wel regelmatig 
teruggevonden worden in de literatuur. ${ }^{6}$ Dit is voornamelijk het geval in (persoonlijke) gedichten en verhalen, zoals "The Canterbury Tales" van Geoffrey Chaucer, waarin veel homoseksuele referenties terug te vinden zijn. ${ }^{7}$ Het werd ook niet vreemd gevonden om de liefde voor hetzelfde geslacht te uiten in briefwisselingen.

\section{Hoe kwamen travestie en genderwisseling voor in de late middeleeuwen?}

Hoewel travestie of genderwisseling absoluut niet alledaags was, was het ook niet volledig ongewoon. Volgens Richard Trexler werd travestie gezien als een vorm van sodomie. ${ }^{8}$ Hoewel het waarschijnlijk minder voorkwam in het noorden van Europa, was travestie na 1475 geen uitzondering meer in Florence. ${ }^{9}$ Vooral in de literatuur, zoals in gedichten, werden mannen vrouwelijk(er) afgeschilderd. ${ }^{10}$ Ook in de "Canterbury Tales" van Geoffrey Chaucer is er sprake van sodomie en de onduidelijkheid over de mannelijkheid van het karakter van de 'Pardoner'11, zo komen er vele elementen van John Rykener's verhaal en karakter terug in dat van de 'Pardoner'. ${ }^{12}$

Ook vrouwen droegen soms kleding die typisch werd geacht voor het andere geslacht, zodat ze sportevenementen en toneelstukken konden bezoeken, en er misschien zelfs in het geheim aan kondern deelnemen. Maar ook dit werd als kwalijk beoordeeld en als teken gezien van de komst van de Antichrist. ${ }^{13}$

In hoeverre werden prostitutie en sodomie getolereerd door de samenleving?

\section{In hoeverre werd prostitutie getolereerd?}

Hoewel prostitutie in het algemeen nog steeds een eerder negatieve bijklank oproept, werd het in de middeleeuwen geaccepteerd als een noodzakelijk kwaad om mannen er voor te behoeden erger kwaad te begaan zoals sodomie, verkrachting en overspel. ${ }^{14}$ Schrijvers als Augustinus ${ }^{15}$ en Thomas van Aquino ${ }^{16}$ zagen het als een middel om homoseksualiteit aan te pakken. ${ }^{17}$ Richard Trexler beweerde dat heteroseksuele prostitutie werd gebruikt om homoseksuelen te bekeren en om het geboortegetal te beïnvloeden. Maar deze bewering is zwak volgens Leah Lydia Otis. Volgens haar was prostitutie een bedreiging van het 
huwelijk. ${ }^{18}$

Hoewel prostitutie dus algemeen als noodzakelijk kwaad werd gezien, veranderde in de late middeleeuwen de mening over de seksuele gedragingen. Zo werd er gepreekt dat lust de man van energie beroofde en hem verzwakte. Michel Menot, een franciscaanse prediker uit de $16^{\mathrm{e}}$ eeuw, kwalificeerde lust in vier verschillende soorten: simpele ontucht, incest, heiligschennis en sodomie. ${ }^{19}$

Heteroseksuele prostitutie kwam zeer vaak voor in taveernes en herbergen, waar in de meeste gevallen de vrouwelijke werknemers geprostitueerd werden door hun mannelijke of zelfs vrouwelijke herbergier. ${ }^{20}$ Hoewel heteroseksuele prostitutie in sommige gevallen wel werd gelegaliseerd of getolereerd, werd homoseksuele prostitutie dat in geen geval. Het bestond zeker, maar het werd niet toegestaan. ${ }^{21}$

Wat ook opmerkelijk is, is dat in het commentaar van de thomistische kardinaal Cajetan op de Secunda secundae (het tweede deel van het tweede boek van de Summa theologica van Thomas van Aquino) uit het begin van de $16^{\mathrm{e}}$ eeuw staat dat 'ontucht, overspel en anderen' wel verboden zijn maar dat het niet verboden is om er geld voor te geven. Dus iemand die de diensten krijgt moet er voor geven wat hij of zij op voorhand beloofd had. ${ }^{22}$ Volgens Thomas van Aquino kon uit het Romeins recht afgeleid worden dat het niet verboden was om prostituees te betalen. ${ }^{23}$ En volgens Huguccio is het vooraf betalen van een prostituée wel een zonde maar haar achteraf belonen niet en bovendien ook nog verplicht. ${ }^{24}$

\section{In hoeverre werden sodomie en travestie getolereerd?}

Karras stelt in haar publicatie "The Medieval World" dat men in de middeleeuwen niet zo zeer aan de homo- of heteroseksualiteit en het geslacht van de mensen tilde, maar voornamelijk aan de subversieve of dominante rol van diegenen in kwestie. Een man penetreerde, of hij dat nu bij een vrouw of bij een man deed, het bleef voor de middeleeuwer hetzelfde. ${ }^{25}$ In de mannelijke samenleving van de middeleeuwen werden sodomie en travestie gezien als vrouwelijk en dus zwak. Het was minderwaardigen werd om die reden ten zeerste afgekeurd. ${ }^{26}$ Anale seks of seks tussen mannen werd niet altijd als sodomie geclassificeerd. Volgens Alan Bray werd in de renaissance in Engeland seks tussen mannen 
getolereerd en werd het niet bestempeld als sodomie. Karras en Boyd zeggen dat als Bray het juist heeft, men er dan van uit kan gaan dat dit ook gold voor eerdere tijden. Ze concluderen hieruit dat dit waarschijnlijk de reden is waarom er zo weinig wettelijke teksten zijn over sodomie. ${ }^{27}$ Het is ook niet duidelijk of Rykener werd veroordeeld voor sodomie. Hoewel Rykener zich bezig hield met prostitutie, werd hij niet geïdentificeerd als een prostituee. Hoewel hij zich bezig hield met sodomie, werd hij niet geïdentificeerd als een sodomiet. Hij werd geïdentificeerd als een man die zijn mannelijke identiteit verwisselde voor die van een vrouw. ${ }^{28}$ De tekst behandelt Rykener dan ook steeds als een vrouw, zoals het volgende zinsdeel aantoont: "modo muliebri", op een vrouwelijke manier. ${ }^{29}$

In de $14^{\mathrm{e}}$ eeuw ontstond de beweging van de Lollarden in Engeland die sodomie ten strengste afkeurden. John Wyclif was hier één van en beschreef in de "Generale Proloog" van zijn bijbel sodomie als moord. Sodomie was letterlijk moord en figuratief simonie. ${ }^{30}$ De Lollarden zelf vonden overigens dat het celibaat leidde tot sodomie of ontucht. ${ }^{31}$ Volgens Wyclif deed het ook vrouwen kwaad omdat mannen opgesloten zaten in kloosters en seks met elkaar hadden. ${ }^{32}$ Maar de Lollarden werden zelf uiteindelijk ook weer beschuldigd van sodomie in een anoniem gedicht, mogelijk uit begin $15^{\mathrm{e}}$ eeuw. ${ }^{33}$

Volgens Rossiaud werd homoseksualiteit al sinds het einde van de $13^{e}$ eeuw gezien als het ergste misdrijf tegen de natuur en

114 de ergste seksuele zonde. ${ }^{34}$ Maar op het Italiaanse schiereiland kwam homoseksualiteit regelmatig voor in bepaalde sociale kringen. ${ }^{35}$ Gerard Noel schreef in zijn boek The Renaissance Popes dat paus Sixtus IV eind $15^{\mathrm{e}}$ eeuw toestemming gaf voor het plegen van sodomie in de zomer omdat het dan "te heet" was. ${ }^{36}$ Maar vanaf de $15^{\mathrm{e}}$ eeuw ging men in Florence, en later ook in de rest van Italië, homoseksualiteit steeds strenger aanpakken. ${ }^{37}$ In Venetië werd bijvoorbeeld na 1406 homoseksualiteit vervolgd. ${ }^{38}$

\section{Wat was de rol van de clerus in de prostitutie?}

Hoewel het geval van Rykener werd behandeld door een stedelijke rechtbank in Engeland, was dit niet gebruikelijk. Voor 1200 had een bisschop rechterlijke macht over zijn gehele diocees. ${ }^{39}$ Seksuele daden werden al vanaf de $12^{\mathrm{e}}$ eeuw behandeld door 
kerkelijke rechtbanken, zowel in Engeland als in de rest van Europa. ${ }^{40}$ Ze gingen over zaken als overspel, prostitutie en soms incest en sodomie. ${ }^{41}$

Het is niet duidelijk of Rykener en zijn medeplichtige verder werden beoordeeld door een kerkelijke rechtbank. ${ }^{42}$ Het is zelfs niet duidelijk of Rykener überhaupt werd veroordeeld aangezien het niet precies duidelijk was of men de daden van hem als bestraffend strafbaar aanzag, omdat hij niet wordt beschreven als prostituee en/of sodomiet maar als 'vrouw'. ${ }^{43}$

In sommige gevallen werden seksuele zaken wel door stedelijke rechtbanken behandeld wanneer ze werden beschouwd als relevant voor de publieke orde..$^{44} \mathrm{Het}$ ging dan vooral over zaken waarbij de clerus betrokken was. De stedelijke rechtbanken wilden al te graag de seksuele misstappen van de clerus aan het licht brengen. Dit was misschien ook de bedoeling van de zaak van Rykener. ${ }^{45}$

De kerkelijke autoriteiten vervolgden niet enkel prostitutie en aanverwante praktijken, ze probeerden ook een graantje mee te pikken van de inkomsten die prostitutie opbracht. In het laatmiddeleeuwse Engeland kregen bepaalde kloosters een deel van de inkomsten, zoals het geval was voor de nonnen van de St. Leonard klooster in Stratford-at-Bow. ${ }^{46}$ Volgens Noel vond zelfs paus Leo $X$ in de $16^{\circ}$ eeuw dat de Romeinse bordelen niet genoeg geld opleverden voor zijn fondsenwerving. ${ }^{47}$

\section{Conclusie}

Hoe ver ging de algemene aanvaarding van sodomie en prostitutie in de late middeleeuwen in Europa?

In het bovenstaande onderzoek heb ik verschillende visies voorgesteld. Aan de ene kant zijn er de auteurs die zeggen dat prostitutie en zelfs sodomie werden getolereerd in de middeleeuwen, zoals Karras en Boyd, Trexler, Hanawalt, Kelly en Noel. Prostitutie zou gezien worden als een noodzakelijk kwaad. Auteurs als Dinshaw, Rossiaud en Otis beschrijven een sterke afkeuring van prostitutie en in het bijzonder van sodomie. Hoewel homoseksualiteit en prostitutie regelmatig voorkomen in de bronnen, zijn de specifieke voorbeelden van zowel sodomie zoals travestie vrij schaars. De brontekst van Rykener geeft 
een heel duidelijk beeld van de gebeurtenissen, maar jammer genoeg is het enig in zijn soort. De brontekst werd per toeval ontdekt door Karras en Boyd. Dit betekent niet dat er niet meer bronnen bestaan; ze moeten gewoon nog gevonden worden. Hopelijk zullen er meerdere bronnen als deze gevonden worden via meer en grondiger speurwerk door historici, zodat we een breder beeld krijgen van de 'seksuele uitspattingen' uit vroegere tijden. Het is immers een zeer interessant onderwerp en er is nog heel veel dat we er nog niet over weten.

\section{LITERATUURLIJST}

\section{Referentie van de brontekst}

'The Questioning of John Rykener, A Male Cross-Dressing Prostitute, 1395'

The medieval Sourcebook - Corporation of London Records Office, Plea and Memoranda Roll A34, m.2 (1395)

In: Boyd, D.L., \& Karras, R.M., The Interrogation of of a Male Transvestite Prostitute in Fourteenth Century London, GLQ 1, 1995, p. $459-465$

\section{Afbeeldingen}

http://i.ehow.com/images/GlobalPhoto/Articles/2030048/ Toronto_Transvestite_Ball_Full.jpg (geraadpleegd op 10 mei 2008)

\section{Uitgegeven bronnen (boeken en artikels in boeken)}

Boyd, D.L., \& Karras, R.M., "Ut cum muliere: a male transvestite prostitute in fourteenth-century London.", In: Fradenburg, L. \& Freccero, C. (ed.) Premodern Sexualities, Routledge, New York, 1996, p. 101-116

Brundage, J.A., "Sin, crime and the pleasures of the flesh: the medieval church judges sexual offences", In: Ed. Linehan, P. \& Nelson, J.L., The Medieval World, Routledge, London, 2001, p. 294-307

Dinshaw, C., "Getting Medievel: Sexualities and Communities, Pre- and Postmodern”, Duke University Press, Durham, 1999 Hanawalt, B.A., "'Of Good and III Repute' Gender and Social Control in Medieval England", Oxford University Press, New York, 1998 
Karras, R.M., "Common women : prostitution and sexuality in medieval England.", Oxford university press, New York, 1996

Karras, R.M. "Sexuality in the middle ages", In: Linehan, P. \& Nelson, J.L., eds., The Medieval World, Routledge, London, 2001, p. $279-293$

Noel, G., "The Renaissance Popes. Culture, power and the making of the Borgia myth.", Contable, Londen, 2006

Otis, L.L., "Prostitution in Medieval Society: The History of an Urban Institution in Languedoc", The University of Chicago Press, Chicago, 1985

Rossiaud, J., "Medieval prostitution", Blackwell, Oxford, 1995 (ed. Cochran, L.G.)

\section{Periodieken (tijdschriften)}

Kelly, H.A., "Bishop, prioress, and bawd in the Stews of Southwark.", In: Speculum: A Journal of Medieval Studies, Volume $75: 2,(2000)$, p. $342-388$

\section{URL's}

Medieval Sourcebook: The Questioning of John Rykener, A Male Cross-Dressing Prostitute, 1395

http://www.fordham.edu/halsall/source/1395rykener.html (geraadpleegd op 14 maart 2008)

\section{NOTEN}

1 The medieval Sourcebook - Corporation of London Records Office, Plea and Memoranda Roll A34, m.2 (1395) In: Boyd, D.L., \& Karras, R.M., The Interrogation of of a Male Transvestite Prostitute in Fourteenth Century London, GLQ 1, 1995, p. 459 - 465.

2 http://www.fordham.edu/halsall/source/1395rykener.html

3 Karras, R.M., \& Boyd, D.L., "Ut cum muliere: a male transvestite prostitute in fourteenth-century London.", In: Fradenburg, L. \& Freccero, C. (ed.) Premodern Sexualities, Routledge, New York, 1996, p. 101

4 Karras, R.M., \& Boyd, D.L., op. cit., p. 101

5 Karras, R.M., "Common women : prostitution and sexuality in medieval England.", Oxford university press, New York, 1996, p. 70

6 Karras, R.M. "Sexuality in the middle ages", In: Linehan, P. \& Nelson, J.L., eds., The Medieval World, Routledge, London, 2001, p. 291

7 Dinshaw, C., "Getting Medievel: Sexualities and Communities, Pre- and Postmodern", Duke University Press, Durham, 1999, p. 102

8 Rossiaud, J., "Medieval prostitution", Blackwell, Oxford, 1995 (ed. 
Cochran, L.G.), p. 113 (in noot 19)

9 Rossiaud, J., op. cit., p. 133

10 Karras, R.M., \& Boyd, D.L., op. cit., p. 107

11 Karras, R.M., \& Boyd, D.L., op. cit., p. 108

12 Dinshaw, C., op. cit., p. 102 en 104

13 Rossiaud, J., op. cit., p. 149

14 Karras, R.M., "Common women : prostitution and sexuality in medieval England.", Oxford university press, New York, 1996, p. 6

15 Kelly, H.A., "Bishop, prioress, and bawd in the Stews of Southwark.", In: Speculum: A Journal of Medieval Studies, Volume 75:2, (2000), p. 342 en 343

16 Kelly, H.A., op. cit., p. 345

17 Otis, L.L., "Prostitution in Medieval Society: The History of an Urban Institution in Languedoc", The University of Chicago Press, Chicago, 1985 , p. 103

18 Otis, L.L., , p. 101

19 Rossiaud, J., op. cit., p. 80

20 Hanawalt, B.A., "'Of Good and III Repute' Gender and Social Control in Medieval England", p. 108

21 Otis, L.L., op. cit., p. 154 (in noot 9)

22 Kelly, H.A., op. cit., p. 347

23 Kelly, H.A., op. cit., p. 348

24 Kelly, H.A., op. cit., p. 348

25 Karras, R.M. "Sexuality in the middle ages", In: Linehan, P. \& Nelson, J.L., eds., The Medieval World, Routledge, London, 2001, p. 290

26 Karras, R.M., \& Boyd, D.L., op. cit., p. 109

27 Karras, R.M., \& Boyd, D.L., op. cit., p. 106

28 Karras, R.M., \& Boyd, D.L., op. cit., p. 108

29 Karras, R.M., \& Boyd, D.L., op. cit., p. 109

30 Dinshaw, C., op. cit., 62-63

11831 Rossiaud, J., op. cit., p. 93

32 Dinshaw, C., op. cit., p. 70

33 Dinshaw, C., op. cit., p. 55 en 65

34 Rossiaud, J., op. cit., p. 88 en 89

35 Rossiaud, J., op. cit., p. 112

36 Noel, G., "The Renaissance Popes. Culture, power and the making of the Borgia myth.", p. 59

37 Rossiaud, J., op. cit., p. 89

38 Rossiaud, J., op. cit., p. 89 (in noot 6)

39 Brundage, J.A., "Sin, crime and the pleasures of the flesh: the medieval church judges sexual offences", In: Ed. Linehan, P. \& Nelson, J.L., The Medieval World, Routledge, London, 2001, p. 304

40 Karras, R.M., \& Boyd, D.L., op. cit., p. 102

41 Karras, R.M., "Common women : prostitution and sexuality in medieval England.", Oxford university press, New York, 1996, p. 14

42 Karras, R.M., \& Boyd, D.L., op. cit., p. 102

43 Karras, R.M., \& Boyd, D.L., op. cit., p. 110 
44 Karras, R.M., \& Boyd, D.L., op. cit., p. 102

45 Karras, R.M., \& Boyd, D.L., op. cit., p. 102

46 Kelly, op. cit., p. 342

47 Noel, G., "The Renaissance Popes. Culture, power and the making of the Borgia myth.", p. 242 